\title{
Determination of Irregular Antibodies in Donated Blood at the National Central Laboratory, Nairobi Kenya
}

\author{
Katsutsu D. A. ${ }^{1}$, Waithaka S. K. ${ }^{2}$, Wesongah J.O. ${ }^{3}$ \\ ${ }^{1}$ Jomo Kenyatta University, Medical Laboratory Sciences Department, Senior Technologist \\ ${ }^{2}$ Mount Kenya University (MKU), Medical Laboratory Sciences Department, Senior Lecturer (PhD) \\ ${ }^{3}$ Jomo Kenyatta University (JKUAT), Medical Laboratory Sciences Department, Lecturer (PhD)
}

\begin{abstract}
Donated blood must at all times seek to save life, correct anemia and provide products that are adequate to save lives. There are irregular antibodies that in normal state are not found in normal serum of an individual and hence a major cause of transfusion reactions, incompatible cross-matches and immunization upon which a second encounter with corresponding antigen may result in unfavorable reactions. Their presence or absence is confirmed by antibody screening test (AST). Objectives wereto determine the prevalence and specificity of irregular antibodies in screened blood, using panel cells for identification.Cross-sectional descriptive study was used. Two hundred and sixty eight blood samples from randomly selected donors were tested out of which twelve donor units tested positive for the presence of irregular antibodies and of this, the most reactions reported in agglutination occurred at room temperature. SAS 9.1 for windows student versionwas used for data analysis.Results obtained were twelve samples (4\%) were found to have irregular antibodies. The blood group with the highest positivity was blood group AB (10\%), while blood group B had the least (3.39\%). These indicates that irregular antibodies are present in all blood groups.Four antibodies identified were Rhesus,Kell,Lewis and Lutheran. kell and Rhesus were $33 \%$ each, Lewis and Lutheran were $17 \%$ each. Rhesus was found high in blood type A, Kell was high in blood type $A B$, Lewis was high in blood type $O$ while Lutheran was high in blood type $B$. Female donors had a higher positive rate (5\%) than males donors (4\%). Study thererfore concludes that a significant proportion of blood donors have irregular antibodies which upon transfusion may lead to transfusion reactions or cause incompatibility during major cross-matches. The study therefore recommends screening of irregular antibodies for all screened blood as a prerequisite to transfusion purposes.
\end{abstract}

Keywords: Irregular antibodies, Donated blood, Transfusion, Antibody screening, Antibody Identification.

\section{Introduction}

Karl Landsteiner, the father of transfusion discovered $\mathrm{ABO}$ blood group and explained the serious reactions that occurs in human as a result of incompatible transfusion [3].The daily occurrence of transfusion led to the discovery of numerous blood groups systems and antibody identification surged to the forefront as sophisticated techniques were developed [11,2].

As much as transfusion is a way of giving life, it has also been described as an avenue for immunization and transfusion of transmissible infectious diseases such as HIV, Hepatitis B Virus, Hepatitis C Virus, Malaria and also Syphilis. All these have been recorded as some of the negative effects of this therapy especially when blood testing is not held as a priority [4]. There has been a rise in transfusion reaction and about one percent of all transfusions are linked to the individual developing antibodies that may eventually lead to the reaction [13]. There are several types of transfusion reactions. Some reactions happen as soon as the transfusion is started, while others take several days or even longer to develop $[10,1]$. If an individual is exposed to a blood group antigen that is not recognized as self, the immune system will produce antibodies that can specifically bind to that particular blood group antigen, and an immunological memory against that antigen is formed. The individual will have become sensitized to that blood group antigen. [4].
Some of the reactions that may occur as a result of irregular antibodies include the following:

An acute immune hemolytic reaction which happens when donor and patient blood types do not match. The patient's antibodies attack the transfused red blood cells, causing them haemolyse and release harmful substances into the bloodstream[1]. Acute hemolytic transfusion reactions occur within 24 hours of the transfusion [6].

Delayed hemolytic reaction is a type of reaction that happens when the body slowly attacks antigens (other than $\mathrm{ABO}$ antigens) on the transfused blood cells. The blood cells are broken down days or weeks after the transfusion. Delayed hemolytic transfusion reactions may occur as soon as 1 day or as late as 14 days after a blood transfusion [8].The aim of this study was to determine irregular antibodies in donor blood that has passed regular screening tests at the National Blood Transfusion Center, Nairobi.

\section{Methodology}

The study took place at National central testing laboratory at Kenyatta national hospital grounds.

This was a Cross sectional descriptive study carried out from November 2014 to March2015. The study was done on samples from donated blood that passed the criteria for transfusion screening. Blood groups, Age of the donor, Gender of the donor and Distribution of irregular antibodies 


\section{International Journal of Science and Research (IJSR) \\ ISSN (Online): 2319-7064}

Index Copernicus Value (2013): 6.14 | Impact Factor (2014): 5.611

were determined using test tube testing. The serum was then subjected to antibody screening test according to [14].

The samples that were antibody screen positive then underwent antibody identification according to [6].

\section{Results}

A total number of 270 units were analyzed. This sample size was arrived at using [4] method. The sex distribution of the donors was as follows: males $210(77.8 \%)$ and the females were $60(22.2 \%)$.

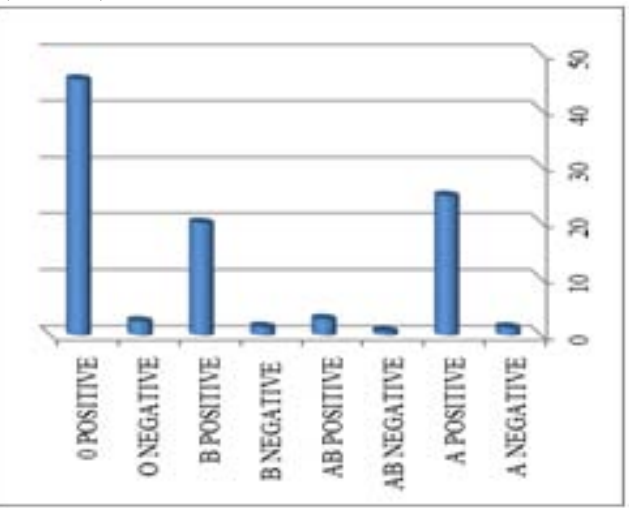

Figure 1: Blood type distribution

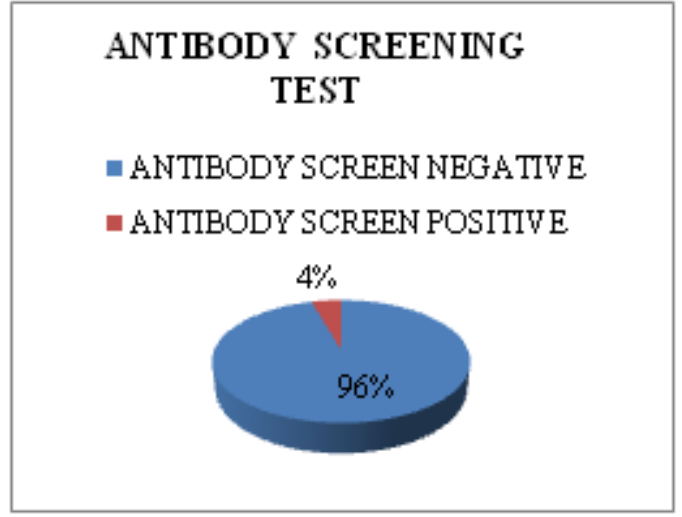

Figure 2: Antibody distribution results

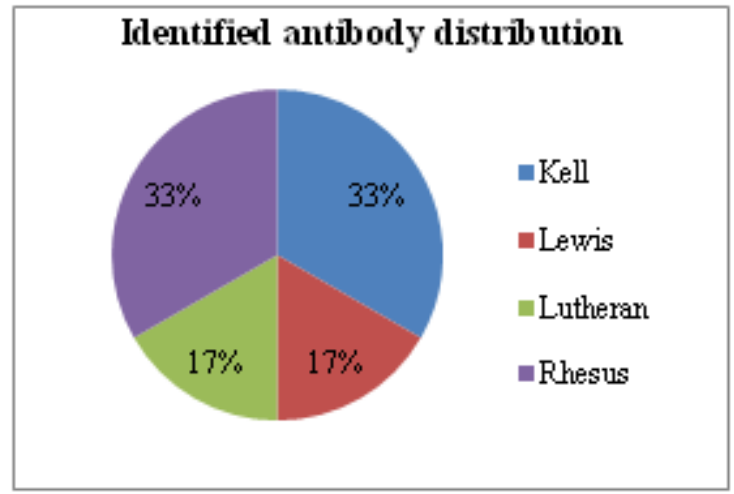

Figure 3: Antibody Screening Test Prevalence per blood type.

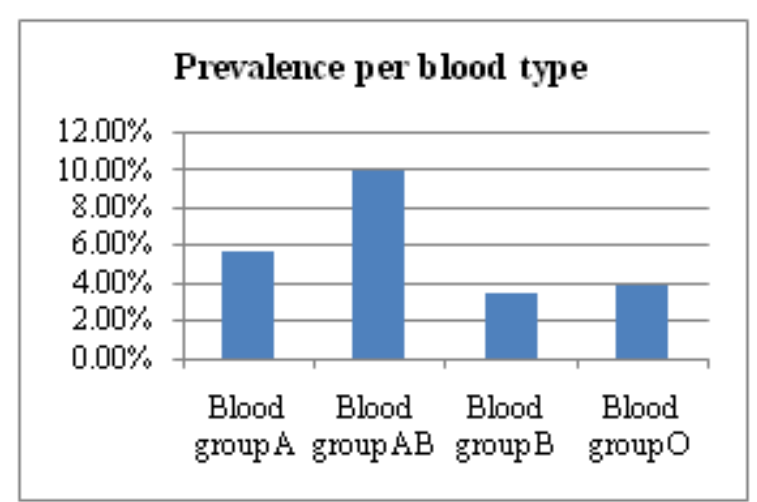

Figure 4: Antibody Screening test results

Table 1: Antibody Irregularity per age per gender

\begin{tabular}{|c|c|c|c|c|}
\hline \multirow[t]{2}{*}{ Age (Years) } & \multirow[t]{2}{*}{ Ast } & \multicolumn{2}{|c|}{ Gender } & \multirow{2}{*}{$\begin{array}{c}\text { Grand } \\
\text { Total }\end{array}$} \\
\hline & & Female & Male & \\
\hline \multicolumn{5}{|l|}{ Total } \\
\hline \multirow[t]{2}{*}{$16-17$} & Negative & 14 & 37 & 51 \\
\hline & Positive & 0 & 3 & 3 \\
\hline \multirow[t]{2}{*}{$18-25$} & Negative & 28 & 119 & 147 \\
\hline & Positive & 2 & 4 & 6 \\
\hline \multirow[t]{2}{*}{$26-30$} & Negative & 4 & 21 & 25 \\
\hline & Positive & 1 & 0 & 1 \\
\hline \multirow[t]{2}{*}{$31-40$} & Negative & 8 & 11 & 19 \\
\hline & Positive & 0 & 0 & 0 \\
\hline \multirow[t]{2}{*}{$41-50$} & Negative & 3 & 10 & 13 \\
\hline & Positive & 0 & 2 & 2 \\
\hline \multirow[t]{2}{*}{$>50$} & Negative & 0 & 3 & 3 \\
\hline & Positive & 0 & 0 & 0 \\
\hline \multicolumn{5}{|l|}{ SUB } \\
\hline \multirow[t]{2}{*}{ TOTAL } & Negative & 57 & 201 & 258 \\
\hline & Positive & 3 & 9 & 12 \\
\hline TOTAL & & 60 & 210 & 270 \\
\hline
\end{tabular}

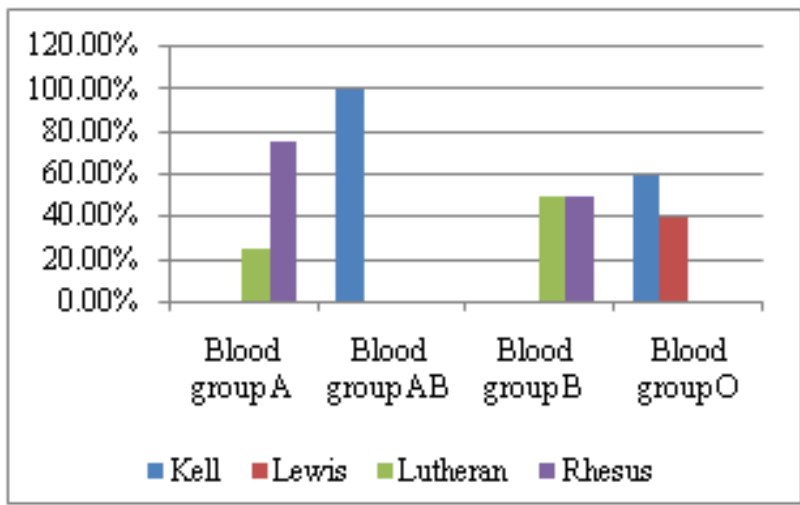

Figure 5: Identified antibody distribution per blood type

\section{Discussion}

The study has brought to fore the blood group distribution within the donors at our centres that shows that amongst all the types, blood group $\mathrm{O}$ had the highest frequency with $48 \%$. This figure is similar to the British Caucasian population where the frequency of group $\mathrm{O}$ is $46 \%$, A $42 \%$, $\mathrm{B} 9 \%$ and $\mathrm{AB} 3 \%$ 19]. The least frequent blood type as per the findings was group $\mathrm{AB}$ negative, $0.7 \%$ hence showing that this blood type is rare amongst the donors, which may lead to difficulty in case of emergencies. From this study it was evident that most donors were males two hundred and ten $(77.8 \%)$ of the sample population, this may have been due to the fact that unlike females who were sixty $(22.2 \%)$. 


\section{International Journal of Science and Research (IJSR) \\ ISSN (Online): 2319-7064}

Index Copernicus Value (2013): 6.14 | Impact Factor (2014): 5.611

The increasing use of blood transfusion has meant that more patients are being immunized by other antigens, especially $\mathrm{Rh}(\mathrm{c}, \mathrm{E})$ and those of the Kell $(\mathrm{K})$, Lewis $\left(\mathrm{Le}^{\mathrm{a}}\right)$ and Lutheran $\left(\mathrm{Lu}^{\mathrm{a}}\right)$ system. These antibodies have all been associated with haemolytic transfusion reactions and HDN [5]. Blood group $\mathrm{O}$ positive had the most presence of irregular antibodies with five out of twelve reactions giving a percentage rate of $41.7 \%$ chances of causing transfusion reactions than other blood types. Females had higher prevalence of irregular antibodies than males due to the fact that they are transfused frequently, often after delivery or having low hemoglobin levels due to pregnancy [7].Ages 41-50 had the highest prevalence of irregular antibodies due to the fact that at that age people could have been transfused more times due to pregnancy, illness, loss of blood due to accidents [16]. The generalized linear model of age and sex regressed on the AST was significant with p-value $(\operatorname{Pr}>F)=0.0077, \mathrm{~F}$ Value $=7.50, \mathrm{df}=6$ which is less than 0.05 level of significance. ANOVA implies that when all the independent variables are included in the model the general model is statistically significant. The goodness of fit (R-square) indicates that the model could explain $55.547 \%$ of the model which is a good fit. The generalized linear model on testing the specific independent variables (gender and age) regressed on the AST using Type III the independent variable regressed had statistical influence on AST as gender p-value $(\operatorname{Pr}>F)=$ $0.0231, \mathrm{~F}$ Value $=277.68, \mathrm{df}=1$ and age p-value $(\operatorname{Pr}>\mathrm{F})=$ $0.00001, \mathrm{~F}$ Value $=24.51, \mathrm{df}=5$ since the age and gender $\mathrm{p}$ value is less than 0.05 level of significance. ANOVA implies that age categories and gender has statistically significance on AST in the model. The gender mean differences between groups (male and female) indicated that gender had a statistical difference on antibody screen positivity (ASP) with female having a higher prevalence compared to male as the mean was greater than the LSD $=0.0297$. The age mean differences between groups indicated that the age category 41-50 and $>51$ had a statistical significance on ASP when compared to the other age groups [9]. The blood type mean differences between groups indicated that none of the blood type had a significant influence on ASP. The irregular antibodies were identified as those belonging to the Rhesus especially $\mathrm{c}$ and $\mathrm{E}$ antigens, Kell, Lutheran and Lewis. Rhesus and Kell were common as compared to Lutheran and Lewis [15].

\section{Conclusion}

The study established that, clean, screened, donated blood had the presence of irregular antibodies which upon transfusion may lead to transfusion reactions and may also be the cause of incompatibility during major cross matches in our health facilities that carry out transfusion services. The government needs to initiate the screening for irregular antibodies, for all screened blood as a prerequisite to transfusion purposes. There is need for further research into this study to include antibody titrations which will establish the strength of the antibodies encountered.This study concurs with [18] Alloimmunization rate of $4.24 \%$ was detected from 306 multiply transfused patients tested and they put emphasis on Serological safety being an integral part of overall safety for blood banks and on importance of issuing antigen negative blood to alloantibody positive patients
Our study however contradicts study conducted by[20] who found that the risk to develop a first red-blood-cells alloantibody increases up to the 40th transfusion and is similar for men and women.

The present study concludes and concurs with [12] that Currently, no data are available on the prevalence of red blood cell (RBC) antibody formation amongst Kenyan patients with multiple transfusion needs, such as patients with sickle cell disease (SCD) or hematological malignancies (HM) and solid (SM) malignancies and therefore there is need to have a data bank with such vital information as their presence cannot be ignored in our blood donation and screening centres.

\section{References}

[1] American Cancer Societyjournal., blood product donation and transfusion possible risks.10/7/2013.

[2] Dean L. (20010)Blood Groups and Red cell antigens, Bethesda (MD): National Center for Biotechnology Information (US).

[3] Denise Hermenils, (2011) Modern Blood Banking and Transfusion Practice- 3rd edition.

[4] Fisher, R. A., Corbet, A. S., and Williams, C. B. (2009). "The relation between the number of species and the number of individuals in a random sample of an animal population." Journal of Animal Ecology,Volume 12: 763-764

[5] Gooch, A., Parker, J., Wray, J. and Qureshi, H., (July 2009). Guideline for blood grouping and antibody testing in pregnancy. British society for Haematology journal, Transfusion medicine 14:59-73.

[6] Hamilton, J.R., Johnson, S.T. and Rudmann, S.V. (2013). Antibody Identification, A case study approach. Journal of Blood transfusion 2011:874.

[7] Hee Han. (2012) Frequency of unexpected antibody and consideration during transfusion.Korean Journal of Anesthesiol

[8] Ibrahim Y.A.Messih, I.Y.A., Ismail, M.A., Saad, A.A. and Azer, M.R. (2012). Screening donated blood for transfusion-transmissible infections. 1-6.

[9] John Wiley \& Sons. (2011) Finnish Medical Society Duodecim. Blood transfusion: indications, Administration and adverse reactions. In: 29927 .Helsinki, Finland: Wiley Interscience

[10] Khademi R, Gharehbaghian A and Karimi G. (Aug 2013) Frequency and specificity of RBC alloantibodies in patients due for surgery in Iran. Indian Journal of Medicine 138, ,pp252-256.

[11] Ki-Ho Ko, Byung-Hoon Yoo,Woo-Yong Lee, JunHeum Yon, Ki-Hyuk Hong and Tae-Hee Han.(2012) Frequency of unexpected antibody and consideration during transfusion.Korean Journal of Anesthesiol.

[12] Mangare, C., Mbugua, A., Maturi, P., Rajab, J., Blasczyk, R., \& Heuft, H. G. (2015). Red cell allo-and autoimmunisation in transfused sickle cell and cancer patients in Kenyatta National Hospital, Nairobi, Kenya. African Journal of Laboratory Medicine, 4(1), 7-pages.

[13] Mugenda and Mugenda. Research methods, qualitative and quantitative approaches, Acts press Nairobi, Kenya; 1999.

[14] Murphy.F.M, Pamphilon.H.D., (2009). Practical 


\section{International Journal of Science and Research (IJSR) \\ ISSN (Online): 2319-7064}

Index Copernicus Value (2013): 6.14 | Impact Factor (2014): 5.611

Transfusion Medicine, Third Edition,

[15] Mwambugu.A and Siulapwa.N,(2012) Frequency and Distribution of RBC Alloantibodies in donated blood at Ndola Central Hospital, Zambia. International Journal of Science and Research (IJSR):2319-7064.

[16] Pahuja S, Gupta SK, Pujani M and Jain M. (2011). The prevalence of irregular erythrocyte antibodies among antenatal women in Delhi. Blood Transfusion ;9:388-393.

[17] Poonsup.S, Supawadee. S, Ratchadaporn. P.(2012). Irregular Antibodies in donated blood of Blood Transfusion Center, Khon Kaen University

[18] Sood, R., Makroo, R. N., Riana, V., \& Rosamma, N. L. (2013). Detection of alloimmunization to ensure safer transfusion practice. Asian journal of transfusion science, 7(2), 135.

[19] Sorenseneta. B.S, Johnsen, S.P, and Jorgensen J. (2008). Complications related to blood donation: a population -based study. Vox Sang 94:132-137.

[20] Zalpuri, S., Zwaginga, J. J., Le Cessie, S., Elshuis, J., Schonewille, H., \& Van der Bom, J. G. (2012). Red-blood-cell alloimmunization and number of red-blood-cell transfusions. Vox sanguinis, 102(2), 144149.

\section{Author Profile}

Damaris A. Katsutsu Is a Senior Technologist at JomoKenyatta University,Medical Laboratory Sciences Department, and a post graduate student at Mount Kenya University. 